\title{
Electrophysiological assessment of retinal functions by ERG in Ischemia/ Reperfusion (I/R) Allium cepa pre-treated mice
}

\author{
Saurabh Kumara, Richa Shrib, Sushmita Kaushikc, Varinder Singh' ${ }^{d}$, Akshay Anand ${ }^{\text {** }}$ \\ a,e Neuroscience Research Lab, Department of Neurology, Postgraduate Institute of Medical Education and Research (PGIMER), Chandigarh, India \\ b,d Department of Pharmaceutical Sciences and Drug Research, Punjabi University, Patiala, India \\ 'Advanced Eye Centre, Postgraduate Institute of Medical Education and Research (PGIMER), Chandigarh, India
}

\section{KEY WORDS}

\section{Allium cepa}

pretreatment

ERG

PPA

Retina

\section{*Corresponding author}

\section{Akshay Anand, PhD}

Neuroscience Research Lab

Department of Neurology

Post Graduate Institute of Medical

Education and Research (PGIMER),

Chandigarh, India

Contact no: +91-9914209090

E-mail: akshay1anand@rediffmail.com

\begin{abstract}
Retinal disorders are the one of the most challenging and complex degenerative diseases that need to be addressed because of rapid increase in the number of affected individuals. Most of the available treatments strategies are inadequate to exert permanent solution to the patients. Therefore, as an alternative approach we wanted to test the efficacy of Allium cepa (A. серa) in an Ischemia/Reperfusion (I/R) mouse model. We orally administered the aqueous extract of $A$. cepa at different dosages $100 \mathrm{mg} / \mathrm{kg}, 200 \mathrm{mg} / \mathrm{kg}, 300 \mathrm{mg} / \mathrm{kg} 24 \mathrm{hrs}$ prior to the surgery. Electroretinogram (ERG) analysis was carried out at 7 day, 21 day, and 28 day after the surgery. ERG recording depicted that $A$. cepa administration is able to increase the implicit time but not at the statistically significant level for which larger sample size and deeper analysis is required.

doi: 10.38205/imcr.010118
\end{abstract}

\section{Introduction}

Repeated failure in treating different neurodegenerative diseases have left no option for the researchers to think about the alternative approaches. Fruits and vegetables are the excellent alternative source to treat such disorders (1). Different studies suggest the potential role of fruits and vegetables in reducing the risk of degenerative diseases $(2,3)$. Flavonoids, a polyphenolic secondary metabolite are known to have antioxidant, anti-inflammatory, and anti-microbial properties. These flavonoids have been used in different in vitro and in vivo models and several studies suggests its protective role in degenerative diseases $(4,5)$.

Eye related disorders are most common degenerative disorders and have very limited scope of permanent cure. However, to overcome this, various traditional approaches like herbal remedy and homeopathy have been employed by ophthalmologist (6). Scientific studies have reported preventive role of onion on different eye related disorders like; Cataract $(7,8)$, Age-related Macular Degeneration (AMD) (9).

Onion bulbs (Allium cepa L.) are the rich source of flavonoid, especially in quercetin. Different groups have elucidated the potential biological activity of $A$. серa as neuroprotective, antioxidant, antiallergic, and anti-inflammatory $(5,10,11)$. Published literature explains that onion extract (OE) lowers the total cholesterol content in rabbits (12) and in rats (13) fed with high cholesterol diet. Protective role of ethanolic extract of $A$. сера was found in case of cognition impairments in streptozotocin induced rat diabetes model (14). The neuroprotective effect of flavonoid is known to exert by two processes: First, by interacting with lipid kinase thereby leading to the inhibition of the apoptosis. Second, by benefiting the vascular system (15).

Retinal ischemia which is a leading cause of blindness, results due to insufficient supply of blood to the retina and is known to be associated with several eye related disorders like glaucoma, diabetic retinopathy, and optic retinopathy (16). There have not been many studies on neuroprotective role of onion in rescuing the retinal ganglion cell death resulting due to retinal ischemia. Therefore, in the present study we have investigated the efficacy of aqueous extract of Allium cepa in rescuing the retinal functions depicted by electroretinogram (ERG) analysis. Ischemia/Reperfusion (I/R) induced retina injured mouse model was used to alter the retinal functions thereby affecting the vision.

ERG is a non-invasive technique used to depict the retinal functions. The ability of ERG to detect and isolate various signals from a different set of retinal neurons makes it a important tool for electrophysiological measures and this can be achieved by controlling/changing the stimulus, light intensity or adaptation, and parameters for data processing (17). Data acquisition in the form of wave pattern is a means to represent and distinguish different retinal cells activity. The wave pattern generally starts in the following pattern: "a-wave" is the first negative deflection and represents the primary retinal neurons (photoreceptors: rods and cones); "b-wave" is the 
positive peak which represents the bipolar cells (17); c-wave originates from retinal pigment epithelium (RPE) cells; oscillatory potentials (OP) originates from inner retina/amacrine cells (18). We used scotopic ERG (dark-adapted mice) for this purpose.

\section{Methods}

\section{Animals}

A C-57BL/6J male 8- to 10-week old mouse was used for the experimentation purpose. The weight of the mice ranges from $25 \mathrm{~g}-30 \mathrm{~g}$. Ethical approval was obtained from animal ethical committee (IAEC) of Post Graduate Institute of Medical Education \& Research (PGIMER), Chandigarh, India. The animals were kept in the sterile cages and temperature and humidity controlled facility of PGIMER animal house with no restriction to food and water. A $12 \mathrm{hr}$ light/dark cycle was followed. The animals were divided into 4 groups (Figure 1).

\section{Experimental groups}

The complete experiment was carried according to the GLP guidelines at Neuroscience Research Laboratory $(19,20)$. The A. cepa extract preparation is detailed in our previous publication (21). Different dosages of A. сера $(100 \mathrm{mg} / \mathrm{kg}, 200 \mathrm{mg} / \mathrm{kg}$, $300 \mathrm{mg} / \mathrm{kg}$ ) was administered 24 hours prior to the surgery. Animals were divided into 4 different groups: group 1 (Injury alone), group 2 (Injury $+100 \mathrm{mg} / \mathrm{kg}$ A. cepa pretreatment), group 3 (Injury $+200 \mathrm{mg} / \mathrm{kg}$ A. cepa pretreatment), and group 4 (Injury $+300 \mathrm{mg} / \mathrm{kg}$ A. cepa pretreatment).

\section{Surgery}

Combination of Xylazine $(50 \mathrm{mg} / \mathrm{ml})$ / Ketamine (1:4 ratio) was used to anesthetize the mice. Intraperitoneal injection (IP) was administrated. Approximately $1.5 \mathrm{~cm}$ incision was made around the neck region. Initially, the CCA was exposed by retracting the muscles. The bifurcation was exposed and ECA was

Male mice

(8-10 weeks)

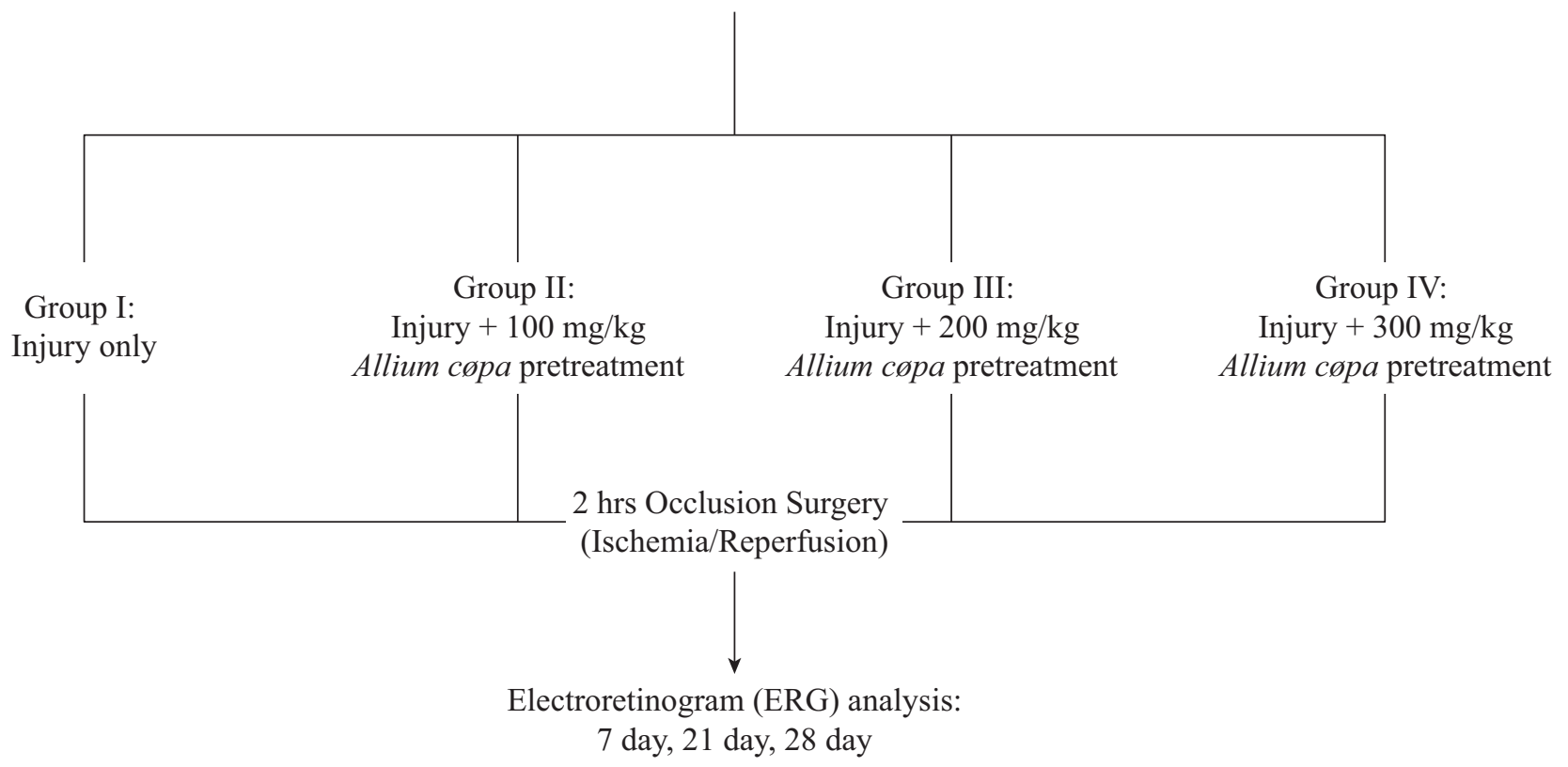

Fig. 1: Representation of the study design.

ligated with a fine suture. Further, the bifurcation of ICA was traced down and PPA was ligated with a $7.0 \mathrm{~mm}$ ethicon suture. The ligation was maintained for $2 \mathrm{hrs}$ after that the ligated sutures were removed and mice was allowed to reperfuse (7 day, 21 day, and 28 day) under the sterile condition. The surgery was carried out under the Leica Stereozoom microscope.

\section{Electroretinography recordings}

Scotopic electroretinography (ERG) was performed to evaluate the function of retina caused due to $2 \mathrm{hrs}$ of ischemia.
The experiment was carried out using iWork ERG instrument (Dover, USA). The ERG data was recorded and evaluated using Labscribe software. ERG was done for all the 4 groups. This experiment was performed once the $24 \mathrm{hrs}$ dark adaptation completed. Anesthesia was administrated intraperitoneally and the animals were kept on heating pad. Tropicamide and methylcellulose eye drops were used to dilate the pupils. Ground electrode was placed on tail, negative electrode in between the ears, and positive electrode was connected to the cornea (19). The readings were taken with flashes of light. 
Right eye represents the 'test eye' whereas the left eye was taken as the 'control eye'. Later on, the amplitudes of different wave were measured.

\section{Results}

Table 1 represents the implicit time and amplitude of both a- and b- waves depicted by ERG. Scotopic ERG was performed on 24 hrs dark adapted mice. We recorded four important parameters, i.e. implicit time to a-wave, implicit time to b-wave, amplitude of a-wave, and amplitude of b-wave. At 7 day, the implicit time to a-wave was found to be $45 \pm 5.78$ for Injury alone, $35 \pm 8.01$ for $100 \mathrm{mg} / \mathrm{kg}$ pretreated, $44.85 \pm 2.86$ for $200 \mathrm{mg} / \mathrm{kg}$ pretreated, and $45.45 \pm 1.72$ for $300 \mathrm{mg} / \mathrm{kg}$ pretreated group. We found that at 21 day the mean implicit time to a wave was highest $43.55 \pm 1.72$ for $200 \mathrm{mg} / \mathrm{kg}$, whereas for injury alone it was $42.25 \pm 4.51$, for $100 \mathrm{mg} / \mathrm{kg}$ group it was $42.27 \pm 1.62$ and for $300 \mathrm{mg} / \mathrm{kg}$ it was $36.95 \pm$ 6.75. With the increase in time points the we observed that at 28 day the implicit time to a wave also increased i.e. $51.13 \pm$ $3.12,43.33 \pm 0.85,44.33 \pm 1.84,46.2 \pm 0.76$ for injury alone, $100 \mathrm{mg} / \mathrm{kg}, 200 \mathrm{mg} / \mathrm{kg}$, and $300 \mathrm{mg} / \mathrm{kg}$, respectively. Positive wave i.e. the b-wave implicit time was found to be $88.27 \pm 9.26$ for injury alone at 7 day, whereas for 21 day it was $77.25 \pm$ 7.67 , and for 28 day it recorded $102.27 \pm 5.72$. For $A$. cepa pretreatment group's implicit time to b wave at 7 day was $88.8 \pm$ 7.17 for $100 \mathrm{mg} / \mathrm{kg}, 90.8 \pm 2.19$ for $200 \mathrm{mg} / \mathrm{kg}$ and $92.3 \pm 1.45$

Table 1: Electroretinogram (ERG) analysis for Injury alone, and A. cepa pretreated groups (100 mg/kg, $200 \mathrm{mg} / \mathrm{kg}, 300 \mathrm{mg} / \mathrm{kg}$ ) at different time points (7 day, 21 day, 28 day) (A). a-wave implicit time; b-wave implicit time (B). a-wave amplitude; b-wave amplitude. The data is represented as mean \pm SE. For Injury alone group sample size was (7 day $(\mathrm{n}=3) ; 21$ day $(\mathrm{n}=4) ; 28$ day $(\mathrm{n}=3)$ ); for $100 \mathrm{mg} / \mathrm{kg}$ pretreated group $(7$ day $(\mathrm{n}=4) ; 21$ day $(\mathrm{n}=3) ; 28$ day $(\mathrm{n}=3)) ;$ for $200 \mathrm{mg} / \mathrm{kg}$ pretreated group (7 day $(\mathrm{n}=4) ; 21$ day $(\mathrm{n}=4) ; 28$ day $(\mathrm{n}=3)) ;$ for $300 \mathrm{mg} / \mathrm{kg} \mathrm{pretreated}$ group (7 day $(\mathrm{n}=4) ; 21$ day $(\mathrm{n}=4) ; 28$ day $(\mathrm{n}=4))$.

\begin{tabular}{|l|c|c|c|c|c|c|c|c|}
\hline A. & \multicolumn{3}{|c|}{ Implicit Time a (Time in ms \pm SE) } & \multicolumn{3}{c|}{ Implicit Time b (Time in ms \pm SE) } \\
\hline Time/Groups & Injury & $\mathbf{1 0 0} \mathbf{~} \mathbf{~} / \mathbf{k g}$ & $\mathbf{2 0 0} \mathbf{~} \mathbf{g} / \mathbf{k g}$ & $\mathbf{3 0 0} \mathbf{~ m g} / \mathbf{k g}$ & Injury & $\mathbf{1 0 0} \mathbf{~} \mathbf{g} / \mathbf{k g}$ & $\mathbf{2 0 0} \mathbf{~ m g} / \mathbf{k g}$ & $\mathbf{3 0 0} \mathbf{~ m g} / \mathbf{k g}$ \\
\hline $\mathbf{7}$ day & $45 \pm 5.78$ & $35 \pm 8.01$ & $44.85 \pm 2.86$ & $45.45 \pm 1.72$ & $88.27 \pm 9.26$ & $88.8 \pm 7.17$ & $90.8 \pm 2.19$ & $92.3 \pm 1.46$ \\
\hline $\mathbf{2 1}$ day & $42.25 \pm 4.51$ & $42.27 \pm 1.62$ & $43.55 \pm 1.72$ & $36.95 \pm 6.75$ & $77.25 \pm 7.67$ & $87.2 \pm 8.25$ & $86.4 \pm 3.89$ & $88.3 \pm 8.09$ \\
\hline $\mathbf{2 8}$ day & $51.13 \pm 3.12$ & $43.33 \pm 0.85$ & $44.33 \pm 1.84$ & $46.2 \pm 0.76$ & $102.27 \pm 5.72$ & $79 \pm 4.06$ & $82 \pm 4.56$ & $89.6 \pm 5.09$ \\
\hline
\end{tabular}

\begin{tabular}{|c|c|c|c|c|c|c|c|c|}
\hline B. & \multicolumn{4}{|c|}{ Amplitude a (Time in $\mathrm{ms} \pm \mathrm{SE}$ ) } & \multicolumn{4}{|c|}{ Amplitude b (Time in $\mathrm{ms} \pm \mathrm{SE}$ ) } \\
\hline Time/Groups & Injury & $100 \mathrm{mg} / \mathrm{kg}$ & $200 \mathrm{mg} / \mathrm{kg}$ & $300 \mathrm{mg} / \mathrm{kg}$ & Injury & $100 \mathrm{mg} / \mathrm{kg}$ & $200 \mathrm{mg} / \mathrm{kg}$ & $300 \mathrm{mg} / \mathrm{kg}$ \\
\hline 7 day & $-0.198 \pm 0.031$ & $-0.192 \pm 0.045$ & $-0.339 \pm 0.071$ & $-0.595 \pm 0.013$ & $0.0163 \pm 0.016$ & $0.021 \pm 0.03$ & $0.007 \pm 0.02$ & $0.086 \pm 0.007$ \\
\hline 21 day & $-0.1025 \pm 0.048$ & $-0.363 \pm 0.05$ & $-0.205 \pm 0.031$ & $-0.407 \pm 0.024$ & $0.0295 \pm 0.024$ & $0.0673 \pm 0.026$ & $0.0617 \pm 0.012$ & $0.078 \pm 0.020$ \\
\hline 28 day & $-0.124 \pm 0.017$ & $-0.188 \pm 0.026$ & $-0.302 \pm 0.029$ & $-0.356 \pm 0.062$ & $0.004 \pm 0.038$ & $0.0163 \pm 0.006$ & $0.1076 \pm 0.035$ & $0.074 \pm 0.044$ \\
\hline
\end{tabular}

for $300 \mathrm{mg} / \mathrm{kg}$. At 21 day we found slight decrease in the implicit time to b-wave i.e. $87.2 \pm 8.25(100 \mathrm{mg} / \mathrm{kg}), 86.4 \pm$ 3.89 (200 mg/kg), $88.3 \pm 8.09$ (300 mg/kg). Similar trends where observed for 28 day where mean implicit time to bwave was recorded as follows: $79 \pm 4.06,82 \pm 4.56$, and $89.6 \pm$ 5.09 for $100 \mathrm{mg} / \mathrm{kg}, 200 \mathrm{mg} / \mathrm{kg}, 300 \mathrm{mg} / \mathrm{kg}$ respectively.

Further, the amplitude for both the waves was recorded. The amplitude of a-wave for injury alone was -0.198 \pm 0.031 (7 day), $-0.1025 \pm 0.048$ (21 day), $-0.124 \pm 0.017$ (28 day); for $100 \mathrm{mg} / \mathrm{kg}$ pretreatment group it was -0.192 \pm 0.045 (7 day), $-0.363 \pm 0.05$ (21 day), $-0.188 \pm 0.026$ (28 day); for $200 \mathrm{mg} / \mathrm{kg}$ pretreatment group it was -0.339 \pm 0.071 ( 7 day), $-0.205 \pm 0.031$ (21 day), $-0.302 \pm 0.029$ (28 day); and for $300 \mathrm{mg} / \mathrm{kg}$ pretreatment group it -0.595 \pm 0.013 (7 day), $-0.407 \pm 0.024$ (21 day), $-0.356 \pm 0.062$ (28 day). Similarly, the mean amplitude of b-wave was as follows: $0.0163 \pm 0.016,0.0295 \pm 0.024,0.004 \pm 0.038$ for injury alone group; $0.021 \pm 0.03,0.0673 \pm 0.026,0.0163 \pm$
0.006 for $100 \mathrm{mg} / \mathrm{kg}$ group; $0.007 \pm 0.02,0.0617 \pm 0.012$, $0.1076 \pm 0.035$ for $200 \mathrm{mg} / \mathrm{kg}$ group; $0.086 \pm 0.007,0.078 \pm$ $0.020,0.074 \pm 0.044$ for $300 \mathrm{mg} / \mathrm{kg}$ A. cepa pretreated group at 7,21 , and 28 day time points respectively. The details of significance level have been incorporated in the supplementary file (Supplementary Table 1).

\section{Discussion}

Retinal ischemia is a serious complication associated with glaucoma, diabetic retinopathy, and optic retinopathy (16). The associated condition may lead to blindness if appropriate and adequate treatments are not given on time. We have established a retinal ischemia mouse model by ligating two important arteries i.e. ophthalmic artery (PPA) and ECA (20). It's a $2 \mathrm{hr}$ occlusion model followed by reperfusion for 3 different time points: 7, 21, and 28-day. Because of the repeated failure (24) and side effects (25) of the available commercial drugs, we wanted to test the alternative approach of testing 
A. cepa (onion) as the pretreatment strategy to explore if it is able to improve the vision or not. Apart from its many biological benefits in the form of antioxidant, anti-inflammatory, and neuroprotective activity (as shown by previous studies) its common availability makes it an important biological product to be tested for its efficacy $(5,10,11)$. For this, 3 different concentrations of aqueous extract of commonly used red onion was tested i.e. $100 \mathrm{mg} / \mathrm{kg}, 200 \mathrm{mg} / \mathrm{kg}$ and $300 \mathrm{mg} / \mathrm{kg}$. The functional efficacy of $A$. серa in the form of retinal wave analysis is very important in retinal degeneration cases and to the best of our knowledge it has not been previously reported in such models. According to standardized protocols the ERG recordings are depicted by three important factors- the instrument setup, intensity of the light stimulus, and animal state (26).

ERG recording depicted that implicit time to a-wave decreased in all the $A$. сера administered groups except for slight increase in $300 \mathrm{mg} / \mathrm{kg}$ in comparison to the Injury alone group for 7-day, however, this decrease was not statistically significant. Similarly, the implicit time to b-wave for both 21-day and 28-day increased throughout the A. cepa administered groups in comparison to the injury alone group. However, for 28-day, the implicit time to $b$-wave was highest for injury alone group followed by $300 \mathrm{mg} / \mathrm{kg}$. From this, it can be said that A.cepa administration is able to increase the implicit time but not at the statistically significant level for which larger sample size and deeper analysis is required. Delay in implicit time a-wave have previously been reported in diseased cases (27). Similarly, reduction in a-wave amplitude has also been reported in certain cases. Mixed results were obtained in case of both amplitude $\mathrm{a}$ - and b- wave. Amplitude a-wave was recorded to be decreased in most of the A. cepa administered groups with respect to the injury alone group. Further, b-wave amplitude was highest at 7 day for $100 \mathrm{mg} / \mathrm{kg}$; at 21 day for $300 \mathrm{mg} / \mathrm{kg}$, and at 28 day for $200 \mathrm{mg} / \mathrm{kg}$. So, from this data it can be concluded that $A$. сера may able to improve the retinal functions depicted by ERG analysis.

\section{Limitations of the study}

Though we have tried to minimise the limitation, factors such as intensity of light stimulus, temperature/humidity, anesthesia, ocular environment, adaptive state, and other technical difficulties affecting the ERG recordings cannot be ruled out. Large sample size and more group like: Injury+ PBS/solvent comparison is needed.

\section{Acknowledgments}

Authors would like to acknowledge the Ministry of AYUSH, Govt. of India for providing the funding (Z.28015/106/2014-HPC(EMR)-AYUSH-A).

\section{Authors Contribution}

SK: Experimentation, data analysis, original writing

AA: Conceptualization, editing of the manuscript, securing funding.
RS: Co-conceptualization

SK: Co-conceptualization

VS: Experimentation

\section{Ethical statement}

All experiments were performed after getting the approval from Institutional Animal Ethical Committee (IAEC) via approval no: 67/IAEC/390R.

\section{Conflicts of interests}

The authors declare that they have no conflict of interest.

\section{Source of funding}

Thanks to ministry of AYUSH file No. (Z.28015/106/2014-HPC (EMR)-AYUSH-A) Government of India

Received Date: 10-02-20; Revised Date: 12-02-20

Accepted Date: 26-02-20

\section{References}

1. Essa MM, Akbar M, Guillemin G. The Benefits of Natural Products for Neurodegenerative Diseases: Springer; 2016.

2. Sofi F, Dinu MR. Nutrition and prevention of chronic-degenerative diseases. Agriculture and agricultural science procedia. 2016;8: 713-7.

3. Jiang X, Huang J, Song D, Deng R, Wei J, Zhang Z. Increased Consumption of Fruit and Vegetables Is Related to a Reduced Risk of Cognitive Impairment and Dementia: Meta-Analysis. Frontiers in aging neuroscience. 2017;9:18.

4. Sarchielli E, Morelli A, Guarnieri G, Iorizzi M, Sgambati E. Neuroprotective effects of quercetin 4'-0- $\beta$-d-diglucoside on human striatal precursor cells in nutrient deprivation condition. Acta histochemica. 2018;120(2):122-8.

5. Shri R, Bora KS. Neuroprotective effect of methanolic extracts of Allium cepa on ischemia and reperfusion-induced cerebral injury. Fitoterapia. 2008;79(2):86-96.

6. Nejabat M, Salehi A, Noorani Azad P, Ashraf MJ. Effects of onion juice on the normal flora of eyelids and conjunctiva in an animal model. Jundishapur journal of microbiology. 2014;7(5):e9678-e.

7. Javadzadeh A, Ghorbanihaghjo A, Bonyadi S, Rashidi MR, Mesgari M, Rashtchizadeh N, et al. Preventive effect of onion juice on seleniteinduced experimental cataract. Indian journal of ophthalmology. 2009;57(3):185.

8. Stefek M, Karasu C. Eye lens in aging and diabetes: effect of quercetin. Rejuvenation research. 2011;14(5):525-34.

9. Agte V, Tarwadi K. The importance of nutrition in the prevention of ocular disease with special reference to cataract. Ophthalmic research. 2010;44(3):166-72.

10. Sato A, Zhang T, Yonekura L, Tamura H. Antiallergic activities of eleven onions (Allium cepa) were attributed to quercetin 4'-glucoside using QuEChERS method and Pearson's correlation coefficient. Journal of Functional Foods. 2015;14:581-9.

11. Singh T, Goel RK. Neuroprotective effect of Allium cepa L. in aluminium chloride induced neurotoxicity. Neurotoxicology. 2015;49:1-7.

12. Movahedian A, Sadeghi H, Ghannadi A, Gharavi M, Azarpajooh S. Hypolipidemic activity of Allium porrum L. in cholesterol-fed rabbits. Journal of medicinal food. 2006;9(1):98-101.

13. Kumari K, Augusti K. Lipid lowering effect of S-methyl cysteine sulfoxide from Allium cepa Linn in high cholesterol diet fed rats. Journal of ethnopharmacology. 2007;109(3):367-71. 
14. Tamtaji OR, Hosseinzadeh H, Talaei SA, Behnam M, Firoozeh SMT, Taghizadeh M, et al. Protective Effects of Red Onion (Allium cepa) Ethanolic Extract on Learning and Memory Impairments in Animal Models of Diabetes. Galen Medical Journal. 2017;6(3): 249-57.

15. Vauzour D, Vafeiadou K, Rodriguez-Mateos A, Rendeiro C, Spencer JPE. The neuroprotective potential of flavonoids: a multiplicity of effects. Genes \& nutrition. 2008;3(3-4):115-26.

16. Minhas G, Morishita R, Anand A. Preclinical models to investigate retinal ischemia: advances and drawbacks. Frontiers in neurology. 2012;3:75.

17. Tomiyama Y, Fujita K, Nishiguchi KM, Tokashiki N, Daigaku R, Tabata K, et al. Measurement of electroretinograms and visually evoked potentials in awake moving mice. PloS one. 2016;11(6).

18. Hema L. Ramkumar KDE, Koushik Tripathy, Peter A. Karth, Usha Rajapuram Kumar, and Vinay A. Shah. Electroretinogram: EyeWiki; [updated 15 November 2019. Available from: https://eyewiki.aao.org/Electroretinogram.

19. Neuroscience Research Lab DoN, Post Graduate Institute of Medical Education and Research, Chandigarh. Redefining Quality Standards in Basic Research Investigations by Broadening the Purview of GLP: Quality Council of India.

20. Bammidi S, Sharma K, Tyagi R, Sharma NK, Anand A. Eye Genetics: The Road Ahead to Quality Standards. Advances in Vision Research, Volume I: Springer; 2017. p. 473-80.
21. Kumar S, Modgil S, Bammidi S, Minhas G, Shri R, Kaushik S, et al. Allium cepa exerts neuroprotective effect on retinal ganglion cells of pterygopalatine artery (PPA) ligated mice. J Ayurveda Integr Med. 2020.

22. Modgil S, Cameotra SS, Sharma VL, Anand A. Early Life Pb Exposure and its Effect on Later Life Retinal Degeneration. Journal of cellular biochemistry. 2017.

23. Minhas G, Prabhakar S, Morishita R, Shimamura M, Bansal R, Anand A Transplantation of lineage-negative stem cells in pterygopalatine artery ligation induced retinal ischemia-reperfusion injury in mice. Molecular and cellular biochemistry. 2017;429(1-2):123-36.

24. Kumar S, Modgil S, Bammidi S, Minhas G, Shri R, Kaushik S, et al. Allium cepa exerts neuroprotective effect on retinal ganglion cells of pterygopalatine artery (PPA) ligated mice. Journal of Ayurveda and Integrative Medicine. 2020.

25. Farkouh A, Frigo P, Czejka M. Systemic side effects of eye drops: a pharmacokinetic perspective. Clinical Ophthalmology (Auckland, NZ). 2016;10:2433.

26. Brandli A, Stone J. Using the electroretinogram to assess function in the rodent retina and the protective effects of remote limb ischemic preconditioning. JoVE (Journal of Visualized Experiments). 2015(100):e52658

27. Hancock HA, Kraft TW. Oscillatory potential analysis and ERGs of normal and diabetic rats. Investigative ophthalmology \& visual science. 2004;45(3):1002-8 


\section{Supplementary Table 1}

\section{POST HOC TESTS}

\section{IMPLICIT TIME A-WAVE}

\section{Multiple Comparisons}

1.1. Dependent Variable: Implicit Time A-Wave: 7 Day

\begin{tabular}{|c|c|c|c|c|c|c|c|}
\hline \multirow[t]{2}{*}{7 Day } & \multirow[t]{2}{*}{ (I) Group } & \multirow[t]{2}{*}{ (J) Group } & \multirow{2}{*}{$\begin{array}{c}\text { Mean } \\
\text { Difference (I-J) }\end{array}$} & \multirow[t]{2}{*}{ Std. Error } & \multirow[t]{2}{*}{ Sig. } & \multicolumn{2}{|c|}{ 95\% Confidence Interval } \\
\hline & & & & & & Lower Bound & Upper Bound \\
\hline \multirow[t]{12}{*}{ Scheffe } & \multirow[t]{3}{*}{ Injury } & Hundred & 10.0000 & 7.6475 & .646 & -15.089 & 35.089 \\
\hline & & Two Hundred & .1500 & 7.6475 & 1.000 & -24.939 & 25.239 \\
\hline & & Three Hundred & -.4500 & 7.6475 & 1.000 & -25.539 & 24.639 \\
\hline & \multirow[t]{3}{*}{ Hundred } & Injury & -10.0000 & 7.6475 & .646 & -35.089 & 15.089 \\
\hline & & Two Hundred & -9.8500 & 7.0803 & .602 & -33.077 & 13.377 \\
\hline & & Three Hundred & -10.4500 & 7.0803 & .557 & -33.677 & 12.777 \\
\hline & \multirow[t]{3}{*}{ Two Hundred } & Injury & -.1500 & 7.6475 & 1.000 & -25.239 & 24.939 \\
\hline & & Hundred & 9.8500 & 7.0803 & .602 & -13.377 & 33.077 \\
\hline & & Three Hundred & -.6000 & 7.0803 & 1.000 & -23.827 & 22.627 \\
\hline & \multirow[t]{3}{*}{ Three Hundred } & Injury & .4500 & 7.6475 & 1.000 & -24.639 & 25.539 \\
\hline & & Hundred & 10.4500 & 7.0803 & .557 & -12.777 & 33.677 \\
\hline & & Two Hundred & .6000 & 7.0803 & 1.000 & -22.627 & 23.827 \\
\hline \multirow{3}{*}{$\begin{array}{l}\text { Dunnett t } \\
(2 \text {-sided })^{a}\end{array}$} & Injury & Three Hundred & -.4500 & 7.6475 & 1.000 & -21.281 & 20.381 \\
\hline & Hundred & Three Hundred & -10.4500 & 7.0803 & .364 & -29.735 & 8.835 \\
\hline & Two Hundred & Three Hundred & -.6000 & 7.0803 & 1.000 & -19.885 & 18.685 \\
\hline
\end{tabular}

1.2. Dependent Variable: Implicit Time A-Wave: 21 Day

\begin{tabular}{|c|c|c|c|c|c|c|c|}
\hline \multirow[t]{2}{*}{21 Day } & \multirow[t]{2}{*}{ (I) Group2 } & \multirow[t]{2}{*}{ (J) Group 2} & \multirow{2}{*}{$\begin{array}{c}\text { Mean } \\
\text { Difference (I-J) }\end{array}$} & \multirow[t]{2}{*}{ Std. Error } & \multirow[t]{2}{*}{ Sig. } & \multicolumn{2}{|c|}{ 95\% Confidence Interval } \\
\hline & & & & & & Lower Bound & Upper Bound \\
\hline \multirow[t]{12}{*}{ Scheffe } & \multirow[t]{3}{*}{ Injury } & Hundred & -.01667 & 6.68074 & 1.000 & -21.9335 & 21.9001 \\
\hline & & Two Hundred & -1.30000 & 6.18516 & .997 & -21.5910 & 18.9910 \\
\hline & & Three Hundred & 5.30000 & 6.18516 & .863 & -14.9910 & 25.5910 \\
\hline & \multirow[t]{3}{*}{ Hundred } & Injury & .01667 & 6.68074 & 1.000 & -21.9001 & 21.9335 \\
\hline & & Two Hundred & -1.28333 & 6.68074 & .998 & -23.2001 & 20.6335 \\
\hline & & Three Hundred & 5.31667 & 6.68074 & .887 & -16.6001 & 27.2335 \\
\hline & \multirow[t]{3}{*}{ Two Hundred } & Injury & 1.30000 & 6.18516 & .997 & -18.9910 & 21.5910 \\
\hline & & Hundred & 1.28333 & 6.68074 & .998 & -20.6335 & 23.2001 \\
\hline & & Three Hundred & 6.60000 & 6.18516 & .770 & -13.6910 & 26.8910 \\
\hline & \multirow[t]{3}{*}{ Three Hundred } & Injury & -5.30000 & 6.18516 & .863 & -25.5910 & 14.9910 \\
\hline & & Hundred & -5.31667 & 6.68074 & .887 & -27.2335 & 16.6001 \\
\hline & & Two Hundred & -6.60000 & 6.18516 & .770 & -26.8910 & 13.6910 \\
\hline \multirow{3}{*}{ 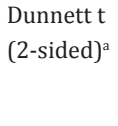 } & Injury & Three Hundred & 5.30000 & 6.18516 & .736 & -11.5473 & 22.1473 \\
\hline & Hundred & Three Hundred & 5.31667 & 6.68074 & .774 & -12.8805 & 23.5138 \\
\hline & Two Hundred & Three Hundred & 6.60000 & 6.18516 & .601 & -10.2473 & 23.4473 \\
\hline
\end{tabular}


1.3. Dependent Variable: Implicit Time A-Wave: 28 Day

\begin{tabular}{|c|c|c|c|c|c|c|c|}
\hline \multirow[t]{2}{*}{28 Day } & \multirow[t]{2}{*}{ (I) Group3 } & \multirow[t]{2}{*}{ (J) Group 3} & \multirow{2}{*}{$\begin{array}{c}\text { Mean } \\
\text { Difference (I-J) }\end{array}$} & \multirow[t]{2}{*}{ Std. Error } & \multirow[t]{2}{*}{ Sig. } & \multicolumn{2}{|c|}{$\mathbf{9 5 \%}$ Confidence Interval } \\
\hline & & & & & & Lower Bound & Upper Bound \\
\hline \multirow[t]{12}{*}{ Scheffe } & \multirow[t]{3}{*}{ Injury } & Hundred & 7.80000 & 2.58314 & .085 & -.9932 & 16.5932 \\
\hline & & Two Hundred & 6.80000 & 2.58314 & .145 & -1.9932 & 15.5932 \\
\hline & & Three Hundred & 4.93333 & 2.41630 & .308 & -3.2919 & 13.1586 \\
\hline & \multirow[t]{3}{*}{ Hundred } & Injury & -7.80000 & 2.58314 & .085 & -16.5932 & .9932 \\
\hline & & Two Hundred & -1.00000 & 2.58314 & .984 & -9.7932 & 7.7932 \\
\hline & & Three Hundred & -2.86667 & 2.41630 & .711 & -11.0919 & 5.3586 \\
\hline & \multirow[t]{3}{*}{ Two Hundred } & Injury & -6.80000 & 2.58314 & .145 & -15.5932 & 1.9932 \\
\hline & & Hundred & 1.00000 & 2.58314 & .984 & -7.7932 & 9.7932 \\
\hline & & Three Hundred & -1.86667 & 2.41630 & .895 & -10.0919 & 6.3586 \\
\hline & \multirow[t]{3}{*}{ Three Hundred } & Injury & -4.93333 & 2.41630 & .308 & -13.1586 & 3.2919 \\
\hline & & Hundred & 2.86667 & 2.41630 & .711 & -5.3586 & 11.0919 \\
\hline & & Two Hundred & 1.86667 & 2.41630 & .895 & -6.3586 & 10.0919 \\
\hline \multirow{3}{*}{$\begin{array}{l}\text { Dunnett } t \\
(2-\text { sided })^{\text {a }}\end{array}$} & Injury & Three Hundred & 4.93333 & 2.41630 & .171 & -1.9099 & 11.7766 \\
\hline & Hundred & Three Hundred & -2.86667 & 2.41630 & .540 & -9.7099 & 3.9766 \\
\hline & Two Hundred & Three Hundred & -1.86667 & 2.41630 & .796 & -8.7099 & 4.9766 \\
\hline
\end{tabular}

\section{IMPLICIT TIME B-WAVE}

2.1. Dependent Variable: Implicit Time B-Wave: 7 Day

\begin{tabular}{|c|c|c|c|c|c|c|c|}
\hline \multirow[t]{2}{*}{7 Day } & \multirow[t]{2}{*}{ (I) Group1 } & \multirow[t]{2}{*}{ (J) Group 1} & \multirow{2}{*}{$\begin{array}{c}\text { Mean } \\
\text { Difference (I-J) }\end{array}$} & \multirow[t]{2}{*}{ Std. Error } & \multirow[t]{2}{*}{ Sig. } & \multicolumn{2}{|c|}{ 95\% Confidence Interval } \\
\hline & & & & & & Lower Bound & Upper Bound \\
\hline \multirow[t]{12}{*}{ Scheffe } & \multirow[t]{3}{*}{ Injury } & Hundred & -.53333 & 8.02095 & 1.000 & -26.8468 & 25.7802 \\
\hline & & Two Hundred & -2.53333 & 8.02095 & .991 & -28.8468 & 23.7802 \\
\hline & & Three Hundred & -4.03333 & 8.02095 & .967 & -30.3468 & 22.2802 \\
\hline & \multirow[t]{3}{*}{ Hundred } & Injury & .53333 & 8.02095 & 1.000 & -25.7802 & 26.8468 \\
\hline & & Two Hundred & -2.00000 & 7.42596 & .995 & -26.3616 & 22.3616 \\
\hline & & Three Hundred & -3.50000 & 7.42596 & .973 & -27.8616 & 20.8616 \\
\hline & \multirow[t]{3}{*}{ Two Hundred } & Injury & 2.53333 & 8.02095 & .991 & -23.7802 & 28.8468 \\
\hline & & Hundred & 2.00000 & 7.42596 & .995 & -22.3616 & 26.3616 \\
\hline & & Three Hundred & -1.50000 & 7.42596 & .998 & -25.8616 & 22.8616 \\
\hline & \multirow[t]{3}{*}{ Three Hundred } & Injury & 4.03333 & 8.02095 & .967 & -22.2802 & 30.3468 \\
\hline & & Hundred & 3.50000 & 7.42596 & .973 & -20.8616 & 27.8616 \\
\hline & & Two Hundred & 1.50000 & 7.42596 & .998 & -22.8616 & 25.8616 \\
\hline \multirow{3}{*}{$\begin{array}{l}\text { Dunnett t } \\
2 \text {-sided) }\end{array}$} & Injury & Three Hundred & -4.03333 & 8.02095 & .924 & -25.8810 & 17.8143 \\
\hline & Hundred & Three Hundred & -3.50000 & 7.42596 & .936 & -23.7270 & 16.7270 \\
\hline & Two Hundred & Three Hundred & -1.50000 & 7.42596 & .994 & -21.7270 & 18.7270 \\
\hline
\end{tabular}


2.2. Dependent Variable: Implicit Time B-Wave: 21 Day

\begin{tabular}{|c|c|c|c|c|c|c|c|}
\hline \multirow[t]{2}{*}{21 Day } & \multirow[t]{2}{*}{ (I) Group2 } & \multirow[t]{2}{*}{ (J) Group 2} & \multirow{2}{*}{$\begin{array}{c}\text { Mean } \\
\text { Difference (I-J) }\end{array}$} & \multirow[t]{2}{*}{ Std. Error } & \multirow[t]{2}{*}{ Sig. } & \multicolumn{2}{|c|}{ 95\% Confidence Interval } \\
\hline & & & & & & Upper Bound & Lower Bound \\
\hline \multirow[t]{12}{*}{ Scheffe } & \multirow[t]{3}{*}{ Injury } & Hundred & -9.95000 & 10.50654 & .826 & -44.4177 & 24.5177 \\
\hline & & Two Hundred & -9.15000 & 9.72716 & .828 & -41.0609 & 22.7609 \\
\hline & & Three Hundred & -11.05000 & 9.72716 & .736 & -42.9609 & 20.8609 \\
\hline & \multirow[t]{3}{*}{ Hundred } & Injury & 9.95000 & 10.50654 & .826 & -24.5177 & 44.4177 \\
\hline & & Two Hundred & .80000 & 10.50654 & 1.000 & -33.6677 & 35.2677 \\
\hline & & Three Hundred & -1.10000 & 10.50654 & 1.000 & -35.5677 & 33.3677 \\
\hline & \multirow[t]{3}{*}{ Two Hundred } & Injury & 9.15000 & 9.72716 & .828 & -22.7609 & 41.0609 \\
\hline & & Hundred & -.80000 & 10.50654 & 1.000 & -35.2677 & 33.6677 \\
\hline & & Three Hundred & -1.90000 & 9.72716 & .998 & -33.8109 & 30.0109 \\
\hline & \multirow[t]{3}{*}{ Three Hundred } & Injury & 11.05000 & 9.72716 & .736 & -20.8609 & 42.9609 \\
\hline & & Hundred & 1.10000 & 10.50654 & 1.000 & -33.3677 & 35.5677 \\
\hline & & Two Hundred & 1.90000 & 9.72716 & .998 & -30.0109 & 33.8109 \\
\hline \multirow{3}{*}{$\begin{array}{l}\text { Dunnett t } \\
(2 \text {-sided })^{\text {a }}\end{array}$} & Injury & Three Hundred & -11.05000 & 9.72716 & .557 & -37.5451 & 15.4451 \\
\hline & Hundred & Three Hundred & -1.10000 & 10.50654 & .999 & -29.7180 & 27.5180 \\
\hline & Two Hundred & Three Hundred & -1.90000 & 9.72716 & .995 & -28.3951 & 24.5951 \\
\hline
\end{tabular}

\subsection{Dependent Variable: Implicit Time B-Wave: 28 Day}

\begin{tabular}{|c|c|c|c|c|c|c|c|}
\hline \multirow[t]{2}{*}{28 Day } & \multirow[t]{2}{*}{ (I) Group3 } & \multirow[t]{2}{*}{ (J) Group 3} & \multirow{2}{*}{$\begin{array}{c}\text { Mean } \\
\text { Difference (I-J) }\end{array}$} & \multirow[t]{2}{*}{ Std. Error } & \multirow[t]{2}{*}{ Sig. } & \multicolumn{2}{|c|}{$95 \%$ Confidence Interval } \\
\hline & & & & & & Upper Bound & Lower Bound \\
\hline \multirow[t]{12}{*}{ Scheffe } & \multirow[t]{3}{*}{ Injury } & Hundred & 23.26667 & 7.36009 & .070 & -1.7875 & 48.3209 \\
\hline & & Two Hundred & 20.26667 & 7.36009 & .123 & -4.7875 & 45.3209 \\
\hline & & Three Hundred & 12.66667 & 6.88473 & .388 & -10.7694 & 36.1027 \\
\hline & \multirow[t]{3}{*}{ Hundred } & Injury & -23.26667 & 7.36009 & .070 & -48.3209 & 1.7875 \\
\hline & & Two Hundred & -3.00000 & 7.36009 & .982 & -28.0542 & 22.0542 \\
\hline & & Three Hundred & -10.60000 & 6.88473 & .529 & -34.0361 & 12.8361 \\
\hline & \multirow[t]{3}{*}{ Two Hundred } & Injury & -20.26667 & 7.36009 & .123 & -45.3209 & 4.7875 \\
\hline & & Hundred & 3.00000 & 7.36009 & .982 & -22.0542 & 28.0542 \\
\hline & & Three Hundred & -7.60000 & 6.88473 & .752 & -31.0361 & 15.8361 \\
\hline & \multirow[t]{3}{*}{ Three Hundred } & Injury & -12.66667 & 6.88473 & .388 & -36.1027 & 10.7694 \\
\hline & & Hundred & 10.60000 & 6.88473 & .529 & -12.8361 & 34.0361 \\
\hline & & Two Hundred & 7.60000 & 6.88473 & .752 & -15.8361 & 31.0361 \\
\hline \multirow{3}{*}{$\begin{array}{l}\text { Dunnett t } \\
(2 \text {-sided })^{a}\end{array}$} & Injury & Three Hundred & 12.66667 & 6.88473 & .230 & -6.8318 & 32.1651 \\
\hline & Hundred & Three Hundred & -10.60000 & 6.88473 & .349 & -30.0984 & 8.8984 \\
\hline & Two Hundred & Three Hundred & -7.60000 & 6.88473 & .591 & -27.0984 & 11.8984 \\
\hline
\end{tabular}




\section{AMPLITUDE a-WAVE}

3.1. Dependent Variable: Amplitude a-Wave: 7 Day

\begin{tabular}{|c|c|c|c|c|c|c|c|}
\hline \multirow{2}{*}{7 Day } & \multirow[t]{2}{*}{ (I) Group 1} & \multirow[t]{2}{*}{ (J) Group 1} & \multirow{2}{*}{$\begin{array}{c}\text { Mean } \\
\text { Difference (I-J) }\end{array}$} & \multirow[t]{2}{*}{ Std. Error } & \multirow[t]{2}{*}{ Sig. } & \multicolumn{2}{|c|}{ 95\% Confidence Interval } \\
\hline & & & & & & Lower Bound & Upper Bound \\
\hline \multirow{12}{*}{ Scheffe } & \multirow{3}{*}{ Injury } & Hundred & -.0062500 & .0701467 & 1.000 & -.236373 & .223873 \\
\hline & & Two Hundred & .1410000 & .0701467 & .310 & -.089123 & .371123 \\
\hline & & Three Hundred & $.3965000^{*}$ & .0701467 & .001 & .166377 & .626623 \\
\hline & \multirow{3}{*}{ Hundred } & Injury & .0062500 & .0701467 & 1.000 & -.223873 & .236373 \\
\hline & & Two Hundred & .1472500 & .0649432 & .222 & -.065802 & .360302 \\
\hline & & Three Hundred & $.4027500^{*}$ & .0649432 & .001 & .189698 & .615802 \\
\hline & \multirow{3}{*}{ Two Hundred } & Injury & -.1410000 & .0701467 & .310 & -.371123 & .089123 \\
\hline & & Hundred & -.1472500 & .0649432 & .222 & -.360302 & .065802 \\
\hline & & Three Hundred & $.2555000^{*}$ & .0649432 & .018 & .042448 & .468552 \\
\hline & \multirow{3}{*}{ Three Hundred } & Injury & $-.3965000^{*}$ & .0701467 & .001 & -.626623 & -.166377 \\
\hline & & Hundred & $-.4027500^{*}$ & .0649432 & .001 & -.615802 & -.189698 \\
\hline & & Two Hundred & $-.2555000^{*}$ & .0649432 & .018 & -.468552 & -.042448 \\
\hline \multirow{3}{*}{$\begin{array}{l}\text { Dunnett t } \\
(2 \text {-sided })^{\mathrm{b}}\end{array}$} & Injury & Three Hundred & $.3965000^{*}$ & .0701467 & .000 & .205433 & .587567 \\
\hline & Hundred & Three Hundred & $.4027500^{*}$ & .0649432 & .000 & .225856 & .579644 \\
\hline & Two Hundred & Three Hundred & $.2555000^{*}$ & .0649432 & .006 & .078606 & .432394 \\
\hline
\end{tabular}

*. The mean difference is significant at the 0.05 level.

3.2. Dependent Variable: Amplitude a-Wave: 21 Day

\begin{tabular}{|c|c|c|c|c|c|c|c|}
\hline \multirow[t]{2}{*}{21 Day } & \multirow[t]{2}{*}{ (I) Group 2} & \multirow[t]{2}{*}{ (J) Group 2} & \multirow{2}{*}{$\begin{array}{c}\text { Mean } \\
\text { Difference (I-J) }\end{array}$} & \multirow[t]{2}{*}{ Std. Error } & \multirow[t]{2}{*}{ Sig. } & \multicolumn{2}{|c|}{ 95\% Confidence Interval } \\
\hline & & & & & & Lower Bound & Upper Bound \\
\hline \multirow[t]{12}{*}{ Scheffe } & \multirow[t]{3}{*}{ Injury } & Hundred & $.2615000^{*}$ & .0570859 & .007 & .074224 & .448776 \\
\hline & & Two Hundred & .1032500 & .0528513 & .332 & -.070134 & .276634 \\
\hline & & Three Hundred & $.3055000^{*}$ & .0528513 & .001 & .132116 & .478884 \\
\hline & \multirow[t]{3}{*}{ Hundred } & Injury & $-.2615000^{*}$ & .0570859 & .007 & -.448776 & -.074224 \\
\hline & & Two Hundred & -.1582500 & .0570859 & .108 & -.345526 & .029026 \\
\hline & & Three Hundred & .0440000 & .0570859 & .896 & -.143276 & .231276 \\
\hline & \multirow[t]{3}{*}{ Two Hundred } & Injury & -.1032500 & .0528513 & .332 & -.276634 & .070134 \\
\hline & & Hundred & .1582500 & .0570859 & .108 & -.029026 & .345526 \\
\hline & & Three Hundred & $.2022500^{*}$ & .0528513 & .021 & .028866 & .375634 \\
\hline & \multirow[t]{3}{*}{ Three Hundred } & Injury & $-.3055000^{*}$ & .0528513 & .001 & -.478884 & -.132116 \\
\hline & & Hundred & -.0440000 & .0570859 & .896 & -.231276 & .143276 \\
\hline & & Two Hundred & $-.2022500^{*}$ & .0528513 & .021 & -.375634 & -.028866 \\
\hline \multirow{3}{*}{$\begin{array}{l}\text { Dunnett t } \\
(2 \text {-sided })^{b}\end{array}$} & Injury & Three Hundred & $.3055000^{*}$ & .0528513 & .000 & .161542 & .449458 \\
\hline & Hundred & Three Hundred & .0440000 & .0570859 & .789 & -.111492 & .199492 \\
\hline & Two Hundred & Three Hundred & $.2022500^{*}$ & .0528513 & .007 & .058292 & .346208 \\
\hline
\end{tabular}

*. The mean difference is significant at the 0.05 level. 
3.3. Dependent Variable: Amplitude a-Wave: 28 Day

\begin{tabular}{|c|c|c|c|c|c|c|c|}
\hline \multirow{2}{*}{28 Day } & \multirow[t]{2}{*}{ (I) Group3 } & \multirow[t]{2}{*}{ (J) Group 3} & \multirow{2}{*}{$\begin{array}{c}\text { Mean } \\
\text { Difference (I-J) }\end{array}$} & \multirow[t]{2}{*}{ Std. Error } & \multirow[t]{2}{*}{ Sig. } & \multicolumn{2}{|c|}{ 95\% Confidence Interval } \\
\hline & & & & & & Lower Bound & Upper Bound \\
\hline \multirow{12}{*}{ Scheffe } & \multirow{3}{*}{ Injury } & Hundred & .0640000 & .0637237 & .800 & -.152920 & .280920 \\
\hline & & Two Hundred & .1776667 & .0637237 & .117 & -.039253 & .394586 \\
\hline & & Three Hundred & $.2315000^{*}$ & .0596081 & .026 & .028590 & .434410 \\
\hline & \multirow{3}{*}{ Hundred } & Injury & -.0640000 & .0637237 & .800 & -.280920 & .152920 \\
\hline & & Two Hundred & .1136667 & .0637237 & .413 & -.103253 & .330586 \\
\hline & & Three Hundred & .1675000 & .0596081 & .114 & -.035410 & .370410 \\
\hline & \multirow{3}{*}{ Two Hundred } & Injury & -.1776667 & .0637237 & .117 & -.394586 & .039253 \\
\hline & & Hundred & -.1136667 & .0637237 & .413 & -.330586 & .103253 \\
\hline & & Three Hundred & .0538333 & .0596081 & .844 & -.149076 & .256743 \\
\hline & \multirow{3}{*}{ Three Hundred } & Injury & $-.2315000^{*}$ & .0596081 & .026 & -.434410 & -.028590 \\
\hline & & Hundred & -.1675000 & .0596081 & .114 & -.370410 & .035410 \\
\hline & & Two Hundred & -.0538333 & .0596081 & .844 & -.256743 & .149076 \\
\hline \multirow{3}{*}{$\begin{array}{l}\text { Dunnett } t \\
(2 \text {-sided })^{b}\end{array}$} & Injury & Three Hundred & $.2315000^{*}$ & .0596081 & .010 & .062682 & .400318 \\
\hline & Hundred & Three Hundred & .1675000 & .0596081 & .052 & -.001318 & .336318 \\
\hline & Two Hundred & Three Hundred & .0538333 & .0596081 & .717 & -.114985 & .222651 \\
\hline
\end{tabular}

*. The mean difference is significant at the 0.05 level.

\section{AMPLITUDE b-WAVE}

4.1. Dependent Variable: Amplitude b-Wave: 7 Day

\begin{tabular}{|c|c|c|c|c|c|c|c|}
\hline \multirow[t]{2}{*}{7 Day } & \multirow[t]{2}{*}{ (I) Group1 } & \multirow[t]{2}{*}{ (J) Group 1} & \multirow{2}{*}{$\begin{array}{c}\text { Mean } \\
\text { Difference (I-J) }\end{array}$} & \multirow[t]{2}{*}{ Std. Error } & \multirow[t]{2}{*}{ Sig. } & \multicolumn{2}{|c|}{$\mathbf{9 5 \%}$ Confidence Interval } \\
\hline & & & & & & Lower Bound & Upper Bound \\
\hline \multirow[t]{12}{*}{ Scheffe } & \multirow[t]{3}{*}{ Injury } & Hundred & -.0046667 & .0343660 & .999 & -.117407 & .108074 \\
\hline & & Two Hundred & .0093333 & .0343660 & .994 & -.103407 & .122074 \\
\hline & & Three Hundred & -.0696667 & .0343660 & .303 & -.182407 & .043074 \\
\hline & \multirow[t]{3}{*}{ Hundred } & Injury & .0046667 & .0343660 & .999 & -.108074 & .117407 \\
\hline & & Two Hundred & .0140000 & .0318167 & .978 & -.090378 & .118378 \\
\hline & & Three Hundred & -.0650000 & .0318167 & .297 & -.169378 & .039378 \\
\hline & \multirow[t]{3}{*}{ Two Hundred } & Injury & -.0093333 & .0343660 & .994 & -.122074 & .103407 \\
\hline & & Hundred & -.0140000 & .0318167 & .978 & -.118378 & .090378 \\
\hline & & Three Hundred & -.0790000 & .0318167 & .165 & -.183378 & .025378 \\
\hline & \multirow[t]{3}{*}{ Three Hundred } & Injury & .0696667 & .0343660 & .303 & -.043074 & .182407 \\
\hline & & Hundred & .0650000 & .0318167 & .297 & -.039378 & .169378 \\
\hline & & Two Hundred & .0790000 & .0318167 & .165 & -.025378 & .183378 \\
\hline \multirow{3}{*}{$\begin{array}{l}\text { Dunnett t } \\
(2 \text {-sided })^{a}\end{array}$} & Injury & Three Hundred & -.0696667 & .0343660 & .160 & -.163274 & .023940 \\
\hline & Hundred & Three Hundred & -.0650000 & .0318167 & .156 & -.151663 & .021663 \\
\hline & Two Hundred & Three Hundred & -.0790000 & .0318167 & .075 & -.165663 & .007663 \\
\hline
\end{tabular}


4.2. Dependent Variable: Amplitude b-Wave: 21 Day

\begin{tabular}{|c|c|c|c|c|c|c|c|}
\hline \multirow[t]{2}{*}{21 Day } & \multirow[t]{2}{*}{ (I) Group 2} & \multirow[t]{2}{*}{ (J) Group 2} & \multirow{2}{*}{$\begin{array}{c}\text { Mean } \\
\text { Difference (I-J) }\end{array}$} & \multirow[t]{2}{*}{ Std. Error } & \multirow[t]{2}{*}{ Sig. } & \multicolumn{2}{|c|}{ 95\% Confidence Interval } \\
\hline & & & & & & Lower Bound & Upper Bound \\
\hline \multirow[t]{12}{*}{ Scheffe } & \multirow[t]{3}{*}{ Injury } & Hundred & -.0378333 & .0306341 & .685 & -.138331 & .062665 \\
\hline & & Two Hundred & -.0322500 & .0283616 & .735 & -.125293 & .060793 \\
\hline & & Three Hundred & -.0485000 & .0283616 & .439 & -.141543 & .044543 \\
\hline & \multirow[t]{3}{*}{ Hundred } & Injury & .0378333 & .0306341 & .685 & -.062665 & .138331 \\
\hline & & Two Hundred & .0055833 & .0306341 & .998 & -.094915 & .106081 \\
\hline & & Three Hundred & -.0106667 & .0306341 & .989 & -.111165 & .089831 \\
\hline & \multirow[t]{3}{*}{ Two Hundred } & Injury & .0322500 & .0283616 & .735 & -.060793 & .125293 \\
\hline & & Hundred & -.0055833 & .0306341 & .998 & -.106081 & .094915 \\
\hline & & Three Hundred & -.0162500 & .0283616 & .953 & -.109293 & .076793 \\
\hline & \multirow[t]{3}{*}{ Three Hundred } & Injury & .0485000 & .0283616 & .439 & -.044543 & .141543 \\
\hline & & Hundred & .0106667 & .0306341 & .989 & -.089831 & .111165 \\
\hline & & Two Hundred & .0162500 & .0283616 & .953 & -.076793 & .109293 \\
\hline \multirow{3}{*}{$\begin{array}{l}\text { Dunnett t } \\
(2 \text {-sided })^{a}\end{array}$} & Injury & Three Hundred & -.0485000 & .0283616 & .261 & -.125752 & .028752 \\
\hline & Hundred & Three Hundred & -.0106667 & .0306341 & .972 & -.094109 & .072775 \\
\hline & Two Hundred & Three Hundred & -.0162500 & .0283616 & .894 & -.093502 & .061002 \\
\hline
\end{tabular}

4.3. Dependent Variable: Amplitude b-Wave: 28 Day

\begin{tabular}{|c|c|c|c|c|c|c|c|}
\hline \multirow[t]{2}{*}{28 Day } & \multirow[t]{2}{*}{ (I) Group 3} & \multirow[t]{2}{*}{ (J) Group 3} & \multirow{2}{*}{$\begin{array}{c}\text { Mean } \\
\text { Difference (I-J) }\end{array}$} & \multirow[t]{2}{*}{ Std. Error } & \multirow[t]{2}{*}{ Sig. } & \multicolumn{2}{|c|}{ 95\% Confidence Interval } \\
\hline & & & & & & Lower Bound & Upper Bound \\
\hline \multirow[t]{12}{*}{ Scheffe } & \multirow[t]{3}{*}{ Injury } & Hundred & -.0123333 & .0541912 & .997 & -.196804 & .172137 \\
\hline & & Two Hundred & -.1036667 & .0541912 & .358 & -.288137 & .080804 \\
\hline & & Three Hundred & -.0700000 & .0506913 & .611 & -.242556 & .102556 \\
\hline & \multirow[t]{3}{*}{ Hundred } & Injury & .0123333 & .0541912 & .997 & -.172137 & .196804 \\
\hline & & Two Hundred & -.0913333 & .0541912 & .458 & -.275804 & .093137 \\
\hline & & Three Hundred & -.0576667 & .0506913 & .736 & -.230223 & .114890 \\
\hline & \multirow[t]{3}{*}{ Two Hundred } & Injury & .1036667 & .0541912 & .358 & -.080804 & .288137 \\
\hline & & Hundred & .0913333 & .0541912 & .458 & -.093137 & .275804 \\
\hline & & Three Hundred & .0336667 & .0506913 & .929 & -.138890 & .206223 \\
\hline & \multirow[t]{3}{*}{ Three Hundred } & Injury & .0700000 & .0506913 & .611 & -.102556 & .242556 \\
\hline & & Hundred & .0576667 & .0506913 & .736 & -.114890 & .230223 \\
\hline & & Two Hundred & -.0336667 & .0506913 & .929 & -.206223 & .138890 \\
\hline \multirow{3}{*}{$\begin{array}{l}\text { Dunnett t } \\
{\text { (2-sided })^{\mathrm{a}}}\end{array}$} & Injury & Three Hundred & -.0700000 & .0506913 & .429 & -.213564 & .073564 \\
\hline & Hundred & Three Hundred & -.0576667 & .0506913 & .570 & -.201231 & .085898 \\
\hline & Two Hundred & Three Hundred & .0336667 & .0506913 & .855 & -.109898 & .177231 \\
\hline
\end{tabular}

${ }^{\text {a }}$ Dunnett t-tests treat one group as a control, and compare all other groups against it. 